\title{
LA RESPONSABILIDAD SOCIAL UNIVERSITARIA EN LA IDENTIDAD CORPORATIVA DE LAS UNIVERSIDADES CHILENAS. UN ANÁLISIS DE CONTENIDO ${ }^{1}$
}

\author{
Ricardo Gaete Quezada (•) \\ Universidad de Antofagasta, Chile
}

\section{RESUMEN}

El artículo analiza la presencia del concepto de responsabilidad social universitaria desarrollado por el proyecto universidad construye país en los actuales planes estratégicos de las universidades que integraron dicha iniciativa. Mediante la técnica de análisis de contenidos se analiza la identidad corporativa de las 14 instituciones participantes del proyecto Universidad Construye País, para identificar el grado de incorporación que actualmente tienen los valores y principios de la universidad socialmente responsable propuestos por dicha iniciativa chilena en la identidad corporativa de dichas instituciones que incluye las declaraciones de misión, visión y valores institucionales de las universidades de la muestra. Los resultados muestran una baja presencia de los valores y principios de la universidad socialmente responsable en la identidad corporativa de las universidades analizadas.

\section{PALABRAS CLAVE:}

responsabilidad social universitaria, universidades chilenas, Universidad Construye País, identidad corporativa, educación superior.

(•) E-mail: ricardo.gaete@uantof.cl

\section{ABSTRACT}

The article analyze the main forms of expression that possesses the university social responsibility in Chile, especially with respect to the "Universidad Construye País" project that developed during the years 2001-2008, establishing the fundamental bases of this model at the national level and with an important recognition at the international level. In addition, discusses the elements that integrate the corporate identity of the 14 participating institutions of "Universidad Construye País" project, to identify the degree of incorporation that have the values and principles of socially responsible university in the current institutional mission and vision statements. The results show a low presence of the values and principles of socially responsible College in the corporate identity of the universities included in the sample.

\section{KEY WORDS :}

corporate identity, university social responsibility, Chilean universities, Universidad Construye País, higher education.

RECEPCIŌN : 20/05/15

ACEPTACIÓN FINAL: 21/01/16 